\title{
SIMULATION OF PULVERIZED COAL FIRED BOILER: REACTION CHAMBER
}

\author{
C. P. Rodrigues, \\ M. A. Lansarin, \\ A. R. Secchi, \\ and T. F. Mendes \\ Grupo de Modelagem, Simulação, Controle e \\ Otimização de Processos (GIMSCOP) \\ Departamento de Engenharia Química \\ Universidade Federal do Rio Grande do Sul \\ Rua Luiz Englert, s/n - Bairro Centro \\ 90040-040, Porto Alegre, RS, Brasil \\ Telefone: (0-xx-51)3316-3952 \\ Fax: (0-xx-51)3316-3277 \\ E-mail: \{cperdomo, marla, arge, \\ talita\}@enq.ufrgs.br
}

\begin{abstract}
This work is part of a joint project to built a computational tool for power plant simulation, dealing specifically with the reaction chamber (place of the boiler where the fuel is burned). In order to describe the conversion of chemical energy to thermal energy, an onedimensional pseudo-homogeneous mathematical model, with variable physical properties, and based on mass and energy balances, was developed. The equations were implemented in the gPROMS simulator and the model parameters were estimated using the module gEST of this software, with experimental data from a large-scale coal-fired utility boiler and kinetic data from the open literature. The results showed that the model predicts the composition of the outlet combustion gas satisfactorily.
\end{abstract}

Keywords: coal combustion, gasification, combustion modeling

\section{NOMENCLATURE}

$\mathrm{Cp}_{\mathrm{i}}$

$\overline{\mathrm{C}} \mathrm{p}_{\mathrm{i}}$

$\mathrm{E}_{\mathrm{i}}$

$\mathrm{F}_{\mathrm{i} 0}$

$\mathrm{F}_{\mathrm{i}}$

$\mathrm{H}_{\mathrm{i}}$

$\mathrm{k}_{0 \mathrm{i}}$

$\mathrm{k}_{\mathrm{i}}$

$\mathrm{MM}_{\mathrm{i}}$

$\mathrm{N}_{\mathrm{i}}$

$\mathrm{P}^{1}$

$\dot{Q}_{i}$

$\dot{\mathrm{Q}}_{\mathrm{i} 0}$

$\mathrm{R}$

$\mathrm{r}_{\mathrm{i}}$

\section{$\mathrm{T}$}

$\mathrm{T}_{\text {ref }}$

$\mathrm{T}_{\text {0air }}$

$\mathrm{T}_{0 \mathrm{~s}}$

$\mathrm{V}$

$\mathrm{V}_{\text {gas }}$ $\mathrm{kJ} \mathrm{kmol}^{-1}$ reactions) specific heat of species i, $\mathrm{kJ} \mathrm{kmol}^{-1} \mathrm{~K}^{-1}$ average specific heat $\left(\sum \alpha_{\mathrm{i}} \mathrm{Cp}_{\mathrm{i}}\right), \mathrm{kJ} \mathrm{kg}^{-1} \mathrm{~K}^{-1}$ activation energy of reaction $\mathrm{i}, \mathrm{kJ} \mathrm{kmol}^{-1}$ molar inflow rate of species $\mathrm{i}, \mathrm{kmols}^{-1}$ molar outflow rate, $\mathrm{kmol} \mathrm{s}^{-1}$ enthalpy of formation at temperature $\mathrm{T}$,

\section{frequency factor of Arrhenius expression} of reaction $\mathrm{i}, \mathrm{m}^{3} \mathrm{~s}^{-1} \mathrm{~kg}^{-1}$ or $\mathrm{m}^{3} \mathrm{~s}^{-1} \mathrm{kmol}^{-1}$ reaction rate coefficient of solid phase $\left(\mathrm{m}^{3} \mathrm{~s}^{-1} \mathrm{~kg}^{-1}\right)$ or gas phase $\left(\mathrm{m}^{3} \mathrm{~s}^{-1} \mathrm{kmol}^{-1}\right)$ molecular weight of species $\mathrm{i}$, and mixture average $\left(\sum \mathrm{y}_{\mathrm{i}} \mathrm{MM}_{\mathrm{i}}\right)$, $\mathrm{kg} \mathrm{kmol}^{-1}$ \section{number of moles of chemical species} total pressure, $\mathrm{kPa}$ outlet energy flow rate, $\mathrm{kJ} \mathrm{s}^{-1}$ inlet energy flow rate, $\mathrm{kJ} \mathrm{s}^{-1}$ universal gas constant, $\mathrm{kJ} \mathrm{kmol}^{-1} \mathrm{~K}^{-1}$ reaction rate given by: $\mathrm{kmol} \mathrm{s}^{-1} \mathrm{~kg}^{-1}$ of carbon present in the char (heterogeneous reactions), or $\mathrm{kmol} \mathrm{s}^{-1} \mathrm{~m}^{-3}$ (homogeneous temperature, $\mathrm{K}$ reference temperature, $25^{\circ} \mathrm{C}(298 \mathrm{~K})$ inlet air temperature, $\mathrm{K}$ inlet coal temperature (solid), $\mathrm{K}$ reaction chamber volume, $\mathrm{m}^{3}$ volume of gases, $\mathrm{m}^{3}$
$\mathrm{V}_{\mathrm{s}} \quad$ volume of solids, $\mathrm{m}^{3}$

$\mathrm{w}_{\mathrm{cz} 0} \quad$ inlet mass flow rate of ash, $\mathrm{kg} \mathrm{s}^{-1}$

$\mathrm{w}_{\mathrm{czv}}$ outlet mass flow rate of light ash, $\mathrm{kg} \mathrm{s}^{-1}$

$\mathrm{w}_{\mathrm{cvf}}$ outlet mass flow rate of heavy ash, $\mathrm{kg} \mathrm{s}^{-1}$

$\mathrm{w}_{\mathrm{i}} \quad$ mass flow rate of species i, $\mathrm{kg} \mathrm{s}^{-1}$

$\mathrm{W}_{\mathrm{i}} \quad$ total weight of species i, $\mathrm{kg}$

$y_{i} \quad$ mole fraction of species $i$

\section{Greek symbols}

$\alpha_{i} \quad$ weight fraction of species i (dry)

$\alpha_{i \text { air }} \quad$ weight fraction of species i from air (dry)

$\alpha_{i \text { MV }}$ weight fraction of volatiles (dry)

$\alpha_{\text {is }}$

$\alpha_{\mathrm{SR}}$

$\Delta \mathrm{H}^{\mathrm{o}}{ }_{\mathrm{rj}}$ weight fraction of species i from coal (dry) weight fraction of sulfur that reacts (dry) enthalpy of reaction $\mathrm{j}$, at constant pressure and reference temperature, $\mathrm{kJ} \mathrm{kmol}^{-1}$

$\Delta \mathrm{H}_{\mathrm{rj}} \quad$ enthalpy of reaction $\mathrm{j}$, at constant pressure and temperature $\mathrm{T}, \mathrm{kJ} \mathrm{kmol}^{-1}$

$\varepsilon \quad$ ratio of the volume occupied by gases and the volume of the reaction chamber (porosity)

$\Omega \quad$ effectiveness factor

$\rho_{\mathrm{s}} \quad$ coal density, $\mathrm{kg} \mathrm{m}^{-3}$

\section{Subscripts}

acc accumulate

air air

C carbon 
$\mathrm{C}_{\mathrm{FIX}}$ fixed carbon

$\mathrm{C}_{\text {ТОт }}$ total carbon

$\mathrm{cz}$ ash

f heavy ash

$\mathrm{G}$ generate

gas gas mixture

IN inlet

MF phase change

MV volatile

$\mathrm{N}$ nitrogen present in coal

oth represents an average between $\mathrm{C}_{2} \mathrm{H}_{4}$ and $\mathrm{C}_{2} \mathrm{H}_{6}$

\section{OUT outlet}

ref reference

$\mathrm{S} \quad$ pulverized coal

SR sulfur that reacts

$\mathrm{v}$ light ash

w wall

\section{INTRODUCTION}

This work is part of a multidisciplinary project to build a computational tool for power plant simulation, which has two coal-fired utility boiler, two steam turbines and two electric energy generators. The thermal energy generation plants are complex systems composed by several interconnected components, where the boiler is among them. The boiler is composed by a reaction chamber (the place where the fuel is burned), the focus of this work, and the parts where water vaporizes and steam are superheated (heat exchange zones).

The combustion process takes place through a group of heterogeneous reactions, in which the reactants and/or the products are in different phases. This process can be modeled in different ways, including totally empirically based relationships until phenomenological models with high degree of detail. A review of multidimensional mathematical models of coal combustion and gasification may be found in Smoot and Smith (1985), Niksa (1996) and Brewster et al. (1993). The significant physical and chemical phenomena that are required to develop a rigorous phenomenological model are (Eaton et al., 1999): (1) gaseous, turbulent fluid mechanics with heat transfer; (2) gaseous, turbulent combustion; (3) radiative energy transport; (4) multiphase, turbulent fluid mechanics; (5) liquid vaporization from the particles or droplets; (6) particle devolatilization; (7) particle oxidation; (8) soot formation; (9) pollutant formation and distribution, and (10) fouling/slagging behavior.
The one-dimensional combustion models have the advantage of reducing the computational time, but provide lower quality results and less quantitative information.

Aiming to build a power plant simulator, a comprehensive one-dimensional pseudohomogeneous mathematical model of the combustion process, with variable physical properties and based on mass and energy balances, was developed in this work. The mathematical equations were implemented in gPROMS simulator (PSE, 2000) and the model parameters were estimated using the module gEST of this software, with experimental data form a large-scale utility boiler and kinetics data from the open literature.

\section{MODELING OF THE REACTION CHAMBER}

Before feeding the coal into the boiler, it is pulverized and stocked in storage tanks. The primary air stream carries the coal into the reaction chamber through the coal burners. The secondary air stream is fed into the boiler to promote the coal dispersion inside the reaction chamber. The air is fed in excess of the stoichiometric amount, varying according to the energy produced in the power plant.

The modeling assumptions and simplifications are the following:

(a) the reaction chamber is modeled as a perfectlystirred tank reactor series, and the main reactions that take place into the chamber are shown in Tab. 1;

Table 1. Information about the most important combustion reactions.

\begin{tabular}{|c|c|c|c|c|}
\hline$N^{o}$ & Reaction & $k_{0 i}$ & \begin{tabular}{|c|}
$E_{i}$ \\
$(\mathrm{~kJ} / \mathrm{kmol})$ \\
\end{tabular} & $\begin{array}{c}\Delta H^{0}{ }_{r j} \times 10^{3} \\
\left(\mathrm{~kJ} / \mathrm{kmol}^{3} \mathrm{at}\right. \\
25^{\circ} \mathrm{C} \\
\end{array}$ \\
\hline 1 & $\mathrm{C}_{(\mathrm{s})}+\mathrm{CO}_{2(\mathrm{~g})} \rightarrow 2 \mathrm{CO}_{(\mathrm{g})}$ & $\begin{array}{l}4.8 \times 10^{10} \\
\mathrm{~m}^{3} \mathrm{~kg}^{-1} \mathrm{~s}^{-1}\end{array}$ & $2.469 \times 10^{5}$ & +172.8 \\
\hline 2 & $\mathrm{C}_{(\mathrm{s})}+\mathrm{H}_{2} \mathrm{O}_{(\mathrm{v})} \rightarrow \mathrm{CO}_{(\mathrm{g})}+\mathrm{H}_{2(\mathrm{~g})}$ & $\begin{array}{l}1.968 \times 10^{6} \\
\mathrm{~m}^{3} \mathrm{~kg}^{-1} \mathrm{~s}^{-1}\end{array}$ & $1.473 \times 10^{5}$ & +131.8 \\
\hline 3 & $\mathrm{C}_{(\mathrm{s})}+\mathrm{O}_{2(\mathrm{~g})} \rightarrow \mathrm{CO}_{2(\mathrm{~g})}$ & $\begin{array}{l}4.65 \times 10^{10} \\
\mathrm{~m}^{3} \mathrm{~kg}^{-1} \mathrm{~s}^{-1}\end{array}$ & $1.247 \times 10^{5}$ & -393.4 \\
\hline 4 & $\mathrm{C}_{(\mathrm{s})}+1 / 2 \mathrm{O}_{2(\mathrm{~g})} \rightarrow \mathrm{CO}_{(\mathrm{g})}$ & $\begin{array}{l}1.395 \times 10^{19} \\
\mathrm{~m}^{3} \mathrm{~kg}^{-1} \mathrm{~s}^{-1}\end{array}$ & $3.59 \times 10^{5}$ & -110.3 \\
\hline 5 & $\mathrm{CO}_{(\mathrm{g})}+\mathrm{H}_{2} \mathrm{O}_{(\mathrm{v})} \rightarrow \mathrm{CO}_{2(\mathrm{~g})}+\mathrm{H}_{2(\mathrm{~g})}$ & $\begin{array}{c}2.978 \times 10^{15} \mathrm{~m}^{3} \\
\mathrm{~s}^{-1} \mathrm{kmol}^{-1}\end{array}$ & $3.90 \times 10^{5}$ & +46.9 \\
\hline 6 & $\mathrm{CO}_{(\mathrm{g})}+1 / 2 \mathrm{O}_{2(\mathrm{~g})} \rightarrow \mathrm{CO}_{2(\mathrm{~g})}$ & \begin{tabular}{|c|}
$3.09 \times 10^{11}$ \\
$\mathrm{~m}^{3} \mathrm{~s}^{-1} \mathrm{kmol}^{-1}$ \\
\end{tabular} & $9.76 \times 10^{4}$ & -283.3 \\
\hline 7 & $\begin{array}{c}\mathrm{H}_{2(\mathrm{~g})}+1 / 2 \mathrm{O}_{2(\mathrm{~g})} \rightarrow \mathrm{H}_{2} \mathrm{O}_{(1)} \\
\mathrm{H}_{2} \mathrm{O}_{(1)} \rightarrow \mathrm{H}_{2} \mathrm{O}_{(\mathrm{v})}\end{array}$ & $\begin{array}{c}8.83 \times 10^{11} \\
\mathrm{~m}^{3} \mathrm{~s}^{-1} \mathrm{kmol}^{-1}\end{array}$ & $9.76 \times 10^{4}$ & $\begin{array}{l}-286.0 \\
+44.5\end{array}$ \\
\hline 8 & $\begin{aligned} \mathrm{CH}_{4(\mathrm{~g})}+2 \mathrm{O}_{2(\mathrm{~g})} & \rightarrow \mathrm{CO}_{2(\mathrm{~g})}+2 \mathrm{H}_{2} \mathrm{O}_{(\mathrm{l})} \\
\mathrm{H}_{2} \mathrm{O}_{(1)} & \rightarrow \mathrm{H}_{2} \mathrm{O}_{(\mathrm{v})}\end{aligned}$ & \multicolumn{2}{|c|}{ Instantaneous } & $\begin{array}{l}-212 \\
+44.5\end{array}$ \\
\hline 9 & $\begin{aligned} \mathrm{C}_{2} \mathrm{H}_{6(\mathrm{~g})}+7 / 2 \mathrm{O}_{2(\mathrm{~g})} & \rightarrow 2 \mathrm{CO}_{2(\mathrm{~g})}+3 \mathrm{H}_{2} \mathrm{O}_{(1)} \\
\mathrm{H}_{2} \mathrm{O}_{(1)} & \rightarrow \mathrm{H}_{2} \mathrm{O}_{(\mathrm{v})}\end{aligned}$ & \multicolumn{2}{|c|}{ Instantaneous } & $\begin{array}{l}-1542.2 \\
+44.5 \\
\end{array}$ \\
\hline 10 & $\begin{aligned} \mathrm{C}_{2} \mathrm{H}_{4(\mathrm{~g})}+3 \mathrm{O}_{2(\mathrm{~g})} & \rightarrow 2 \mathrm{CO}_{2(\mathrm{~g})}+2 \mathrm{H}_{2} \mathrm{O}_{(1)} \\
\mathrm{H}_{2} \mathrm{O}_{(1)} & \rightarrow \mathrm{H}_{2} \mathrm{O}_{(\mathrm{v})}\end{aligned}$ & \multicolumn{2}{|c|}{ Instantaneous } & $\begin{array}{l}-1412.1 \\
+44.5\end{array}$ \\
\hline
\end{tabular}


(b) Eaton et al. (1999) reported that $\mathrm{NO}_{\mathrm{x}}$ emitted to the atmosphere from combustion fuels consists mostly of nitric oxide (NO). They mentioned that the nitrogen bonds common in coal are easier to be broken than the nitrogen bonds in molecular nitrogen, and also that the fuel NO typically accounts for $75-95 \%$ of the total NO in coal combustors. Then, in this work it was considered that all NO formed during the coal combustion comes from the nitrogen present in the coal composition;

(c) the released sulfur of coal analysis may either remain in the released ash $\left(\mathrm{S}_{\mathrm{cz}}\right)$ or react $\left(\mathrm{S}_{\mathrm{R}}\right)$. The remaining sulfur in the ash was considered of the same magnitude as the sulfur trioxide determined by NBR 8297 , although this method was not applied to the released ash in the industrial utility, but with released ash in the ultimate coal analysis;

(d) the water present in the coal vaporizes immediately, taking part of the reactions;

(e) the char composition is fixed carbon, nitrogen, hydrogen, sulfur, and oxygen, and these elements are specified by NBR 8299, ASTM D-5373, and ASTM D-4239;

(f) the amount of volatile products depends on temperature and rate of heating (Dutta et al., 1977; Howard, 1963; Roberts and Harris, 2000; Thurgood and Smoot, 1979). In order to agree with the above modeling assumption, the total amount of volatiles released from the coal particle were considered of the same magnitude as the volatiles determined by NBR 8290 ;

(g) the volatile products from pyrolisis are $\mathrm{CH}_{4}, \mathrm{H}_{2}$, $\mathrm{CO}_{2}, \mathrm{CO}, \mathrm{H}_{2} \mathrm{O}$ and other species, and their weight fractions, $\alpha_{i}$, are estimated by expressions provided by Weimer and Clough (1981);

(h) the gas phase is considered an ideal gas;

(i) methane and other hydrocarbons are instantaneously converted into $\mathrm{CO}_{2}$ and $\mathrm{H}_{2} \mathrm{O}$ by reactions 8-10 shown in Tab. 1, and their reaction heat, as well as the resulting amounts of $\mathrm{CO}_{2}$ and $\mathrm{H}_{2} \mathrm{O}$ are added to the respective balances;

(j) the ratio between the rate of reactions 3 and 4 of Tab. 1 are estimated by the correlation provided by Arthur (1951) and Mitchell (1988);

(k) the heterogeneous reactions which take place in the surface of the particle are of first order, as in Weimer and Clough (1981) and kinetically controlled, and the homogeneous reactions which take place in the gas phase are of overall second order, as in Eaton et al. (1999).

The kinetics constants and the reaction rates were expressed by the Arrhenius equation; where $\mathrm{k}_{0 \mathrm{i}}$ is the frequency factor for reaction $i$ and $\mathrm{E}_{\mathrm{i}}$ is the activation energy of the reaction $i$. The kinetics data and the heat of reaction $\left(\Delta \mathrm{H}_{\mathrm{ri}}^{0}\right)$, shown in Tab. 1, were compiled from the open literature (Weimer and Clough, 1981; Kanury, 1975; Perry, 1999).

The rates of reaction were given by Eqs. (1) and (2), where $r_{i}$ is expressed in $\mathrm{kmol} \mathrm{s}^{-1} \mathrm{~kg}^{-1}$ when the reaction is heterogeneous and in $\mathrm{kmols}^{-1} \mathrm{~m}^{-3}$ when the reaction is homogeneous; $\mathrm{k}_{\mathrm{i}}$ is the reaction rate coefficient for reaction $\mathrm{i}$ at the gas or solid phase, $\mathrm{N}_{\mathrm{j}}$ is the number of moles of species $\mathrm{j}$ ( $\mathrm{kmol}), \mathrm{V}$ is the chamber volume $\left(\mathrm{m}^{3}\right)$ and $\mathrm{V}_{\mathrm{g}}$ is the volume occupied by the gas phase into the chamber.

a) Gas-solid reactions:

$$
\square \mathrm{r}_{\mathrm{i}} \frac{\mathrm{k}_{\mathrm{i}} \mathrm{N}_{\mathrm{j}}}{\mathrm{V}}
$$

b) Gas-phase reactions:

$$
\square \mathrm{r}_{\mathrm{i}} \frac{\mathrm{k}_{\mathrm{i}} \mathrm{N}_{\mathrm{j}} \mathrm{N}_{\mathrm{k}}}{\mathrm{V}_{\mathrm{g}}^{2}}
$$

\section{Mass Balance}

Table 2 contains the mass balance equations, where $\mathrm{F}_{\mathrm{i} 0}$ and $\mathrm{F}_{\mathrm{i}}$ are the flow rates of species $\mathrm{i}$ into and out of the reaction chamber, respectively; $\Omega$ is the effectiveness factor, $\mathrm{W}_{\mathrm{s}}$ is the total weight of solids present in the chamber and $\varepsilon$ is the volume fraction occupied by the gas phase.

Table 2. Mass balance equations for the

\begin{tabular}{|c|c|}
\hline $\mathrm{C}$ & $\frac{\mathrm{dN}_{\mathrm{C}}}{\mathrm{dt}}=\mathrm{F}_{\mathrm{C}_{0}}-\mathrm{F}_{\mathrm{C}}+\Omega \quad \mathrm{W}_{\mathrm{s}}\left(\mathrm{r}_{1}+\mathrm{r}_{2}+\mathrm{r}_{3}+\mathrm{r}_{4}\right)$ \\
\hline $\mathrm{O}_{2}$ & $\frac{\mathrm{dN}_{\mathrm{O}_{2}}}{\mathrm{dt}}=\mathrm{F}_{\mathrm{O}_{20}}-\mathrm{F}_{\mathrm{O}_{2}}+\Omega \mathrm{W}_{\mathrm{s}}\left(\mathrm{r}_{3}+\frac{\mathrm{r}_{4}}{22}\right)+\frac{\mathrm{V} \varepsilon}{}\left(\mathrm{r}_{6}+\mathrm{r}_{7}\right)$ \\
\hline $\mathrm{H}_{2} \mathrm{O}$ & $\frac{\mathrm{dN}_{\mathrm{HQ}}(\mathrm{v})}{\mathrm{dt}}=\mathrm{F}_{\mathrm{H}_{2} \mathrm{O}_{(\mathrm{v})}}-\mathrm{F}_{\mathrm{H}_{2} \mathrm{O}_{(\mathrm{v})}}+\Omega \quad \mathrm{W}_{\mathrm{s}} \mathrm{r}_{2}+\mathrm{V} \varepsilon\left(\mathrm{r}_{5}-\mathrm{r}_{7}\right)$ \\
\hline $\mathrm{CO}_{2}$ & $\frac{\mathrm{dN}_{\mathrm{CO}_{2}}}{\mathrm{dt}}=\mathrm{F}_{\mathrm{CO}_{2_{0}}}-\mathrm{F}_{\mathrm{CO}_{2}}+\Omega \mathrm{W}_{\mathrm{s}}\left(\mathrm{r}_{1}-\mathrm{r}_{3}\right)-\mathrm{V} \varepsilon\left(\mathrm{r}_{5}+\mathrm{r}_{6}\right)$ \\
\hline $\mathrm{CO}$ & $\frac{\mathrm{dN}_{\mathrm{CO}}}{\mathrm{dt}}=\mathrm{F}_{\mathrm{CO}_{0}}-\mathrm{F}_{\mathrm{CO}}-\Omega \quad \mathrm{W}_{\mathrm{s}}\left(2 \mathrm{r}_{1}+\mathrm{r}_{2}+\mathrm{r}_{4}\right)+\mathrm{V} \varepsilon\left(\mathrm{r}_{5}+\mathrm{r}_{6}\right)$ \\
\hline $\mathrm{H}_{2}$ & $\frac{\mathrm{dN}_{\mathrm{H}_{2}}}{\mathrm{dt}}=\mathrm{F}_{\mathrm{H}_{20}}-\mathrm{F}_{\mathrm{H}_{2}}+\Omega \quad \mathrm{W}_{\mathrm{s}} \mathrm{r}_{2}+\mathrm{V} \varepsilon\left(\mathrm{r}_{7}-\mathrm{r}_{5}\right)$ \\
\hline NO & $\frac{\mathrm{dN}_{\mathrm{NO}}}{\mathrm{dt}}=\mathrm{F}_{\mathrm{NO}_{0}}-\mathrm{F}_{\mathrm{NO}}$ \\
\hline $\mathrm{N}_{2}$ & $\frac{\mathrm{dN}_{\mathrm{N}_{2 \mathrm{ar}}}}{\mathrm{dt}}=\mathrm{F}_{\mathrm{N}_{2 a \mathrm{i}}}-\mathrm{F}_{\mathrm{N}_{2 \mathrm{air}}}$ \\
\hline $\mathrm{Ar}$ & $\frac{\mathrm{dN}_{\mathrm{Arg}_{\mathrm{ir}}}}{\mathrm{dt}}=\mathrm{F}_{\mathrm{Arg}_{\mathrm{air}}}-\mathrm{F}_{\mathrm{Arg}}$ \\
\hline $\mathrm{SO}_{2}$ & $\frac{\mathrm{dN}_{\mathrm{SO}_{2}}}{\mathrm{dt}}=\mathrm{F}_{\mathrm{SO} Q \mathrm{~S}} \sigma^{\mathrm{F}}$ \\
\hline Ash & $\frac{\mathrm{dW}}{\mathrm{dt}}=\mathrm{w}_{\mathrm{cz}_{0}}-\mathrm{w}_{\mathrm{cz}_{\mathrm{v}}}-\mathrm{w}_{\mathrm{cz}_{\mathrm{f}}}$ \\
\hline
\end{tabular}
components (mole base). 
The expressions for the flow rates of $i$ into the chamber are shown in Tab. 3, where $\alpha_{i}$ is the weight fraction of volatile i released from the solid particles, $\mathrm{C}_{\mathrm{FIX}}$ is the weight fraction of fixed carbon, $\mathrm{MM}_{\mathrm{i}}$ is the molecular weight of species $\mathrm{i}, \mathrm{w}_{\mathrm{s}}$ is the solid inflow rate and $\mathrm{w}_{\text {air }}$ is the air inflow rate.

The inlet and outlet flow rates of $i$ present in the combustion gas of the chamber are, respectively, given by Eq. (3) and (4):

$$
\begin{gathered}
\mathrm{F}_{\text {gas }_{0}} \prod_{\mathrm{i}_{1}}^{8} \mathrm{~F}_{\mathrm{i}_{0}} \\
\mathrm{~F}_{\text {gas }} \mathrm{F}_{\text {gas }_{0}} \square 0,5 \mathrm{VH耳}_{6} \square \mathrm{r}_{7} \square: \mathrm{W}_{\mathrm{s}} \mathrm{G}_{1} \square \mathrm{r}_{2} \square 0,5 \mathrm{r}_{4} \square
\end{gathered}
$$

where the subscript $\mathrm{i}$ represents the following gas components: $\mathrm{O}_{2}, \mathrm{H}_{2} \mathrm{O}, \mathrm{CO}_{2}, \mathrm{CO}, \mathrm{H}_{2}, \mathrm{NO}, \mathrm{N}_{2}, \mathrm{Ar}$.

The input ash flow rate is expressed by:

$$
\mathrm{w}_{\mathrm{cz}_{0}} \quad \mathrm{cz} \cdot \mathrm{w}_{\mathrm{s}}
$$

where $\mathrm{cz}$ is the weight fraction of ash released from solid particle.

The output flow rates for each component in the reaction chamber are given by:

$$
\begin{gathered}
\mathrm{F}_{\mathrm{C}} \frac{0,01 \mathrm{w}_{\mathrm{cz}}}{\mathrm{MM}_{\mathrm{C}}} \\
\mathrm{F}_{\mathrm{i}} \quad \mathrm{F}_{\text {gas }} \mathrm{y}_{\mathrm{i}}
\end{gathered}
$$

where the mole fraction of combustion gas species are calculated from:

$$
\begin{aligned}
& \mathrm{y}_{\mathrm{i}} \frac{\mathrm{N}_{\mathrm{i}}}{\mathrm{N}_{\text {gas }}} \\
& 0 \mathrm{~N}_{\text {gas }} !_{\mathrm{i}}^{8} \mathrm{~N}_{\mathrm{i}}
\end{aligned}
$$

\begin{tabular}{|c|c|}
\hline C & $\mathrm{F}_{\mathrm{C}_{0}}=\frac{\mathrm{C}_{\mathrm{FIX}} \mathrm{w}_{\mathrm{s}}}{\mathrm{MM}_{\mathrm{C}}}$ \\
\hline $\mathrm{O}_{2}$ & $\mathrm{~F}_{\mathrm{O}_{20}}=\frac{\alpha_{\mathrm{O}_{2} \text { air }} \mathrm{w}_{\text {air }}}{\mathrm{MM}_{\mathrm{O}_{2}}}-2\left(\frac{\alpha_{\mathrm{CH}_{4}} \mathrm{w}_{\mathrm{s}}}{\mathrm{MM}_{\mathrm{CH}_{4}}}\right)-\frac{13}{2}\left(\frac{\alpha_{\mathrm{oth}} \mathrm{w}_{\mathrm{s}}}{\mathrm{MM} \text { oth }}\right)$ \\
\hline $\mathrm{H}_{2} \mathrm{O}$ & 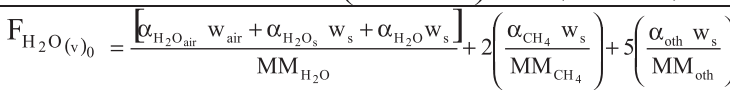 \\
\hline $\mathrm{CO}_{2}$ & $\mathrm{~F}_{\mathrm{CO}_{20}}=\left(\frac{\alpha_{\mathrm{CH}_{4}} \mathrm{w}_{\mathrm{s}}}{\mathrm{MM}_{\mathrm{CH}_{4}}}\right)+4\left(\frac{\alpha_{\text {oth }} \mathrm{w}_{\mathrm{s}}}{\mathrm{MM}_{\text {oth }}}\right)+\frac{\alpha_{\mathrm{CO}_{2}} \mathrm{w}_{\mathrm{s}}}{\mathrm{MM}_{\mathrm{CO}_{2}}}$ \\
\hline $\mathrm{CO}$ & $\mathrm{F}_{\mathrm{CO}_{0}}=\frac{\alpha_{\mathrm{CO}} \mathrm{w}_{\mathrm{s}}}{\mathrm{M}_{\mathrm{CO}}}$ \\
\hline $\mathrm{H}_{2}$ & $\mathrm{~F}_{\mathrm{H}_{20}}=\frac{\alpha_{\mathrm{H}_{2}} \mathrm{~W}_{\mathrm{s}}}{\mathrm{MM}_{\mathrm{H}_{2}}}$ \\
\hline $\mathrm{NO}$ & $\mathrm{F}_{\mathrm{NO}_{0}}=\frac{\alpha_{\mathrm{NO}} \mathrm{w}_{\mathrm{s}}}{\mathrm{MM}_{\mathrm{NO}}}$ \\
\hline $\mathrm{N}_{2}$ & $\mathrm{~F}_{\mathrm{N}_{2_{\mathrm{o}}}}=\frac{\alpha_{\mathrm{N}_{2_{\text {air }}}} \mathrm{w}_{\text {air }}}{\mathrm{MM}_{\mathrm{N}_{2}}}$ \\
\hline $\mathrm{Ar}$ & $\mathrm{F}_{\mathrm{Arg}}=\frac{\alpha_{\mathrm{Ar}_{\mathrm{air}}} \mathrm{W}_{\text {air }}}{\mathrm{MM}_{\mathrm{Ar}}}$ \\
\hline $\mathrm{SO}_{2}$ & $\mathrm{~F}_{\mathrm{SO}_{20}}=\frac{\alpha_{\mathrm{SR}} \mathrm{w}_{\mathrm{s}}}{\mathrm{MM}_{\mathrm{SO}_{2}}}$ \\
\hline
\end{tabular}

Table 3. Input flow rates to the reaction chamber for the components.

The total weight of solid particles and gas accumulated in the reaction chamber are given by:

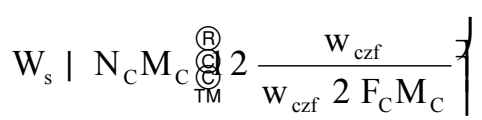

$$
\begin{aligned}
& \mathrm{W}_{\mathrm{g}} \quad \mathrm{N}_{\text {gas }} \mathrm{MM}_{\text {gas }}
\end{aligned}
$$

\section{Energy Balance}

For the energy balance, the following terms were included: (1) rate of energy added to the system by the solid particles, air, and water mass flow into the chamber; (2) rate of energy leaving the system by the gas and ash mass flow out of the chamber; (3) energy flow rate out of the system to the waterwall; (4) heat generation rate by the chemical reaction, and (5) rate of energy accumulation within the system. Then, the energy balance becomes:

$$
\dot{\mathrm{Q}}_{\mathrm{ACC}} \quad \dot{\mathrm{Q}}_{\mathrm{IN}} \square \dot{\mathrm{Q}}_{\mathrm{OUT}} \square \dot{\mathrm{Q}}_{\mathrm{G}}
$$

where:

$$
\dot{\mathrm{Q}}_{\mathrm{IN}} \quad \dot{\mathrm{Q}}_{\mathrm{s}_{0}} \square \dot{\mathrm{Q}}_{\text {air }_{0}} \square \dot{\mathrm{Q}}_{\mathrm{H}_{2} \mathrm{O}_{0}}
$$




$$
\begin{aligned}
& \dot{\mathrm{Q}}_{\mathrm{OUT}} \quad \dot{\mathrm{Q}}_{\mathrm{w}} \square \dot{\mathrm{Q}}_{\mathrm{gas}} \square \dot{\mathrm{Q}}_{\mathrm{cz}}
\end{aligned}
$$

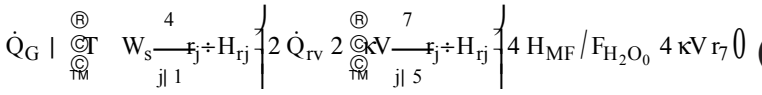

Substituting these expressions into Eq. (12) the energy balance becomes:

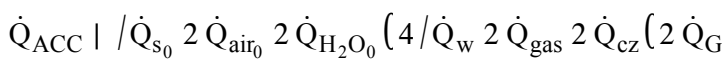

where:

$$
\begin{aligned}
& \dot{\mathrm{Q}}_{\mathrm{s}_{0}} \quad \mathrm{w}_{\mathrm{s}} \underset{\mathrm{T}_{\mathrm{ref}}}{\mathrm{T}_{\mathrm{s} 0}} \overline{\mathrm{C}} \mathrm{p}_{\mathrm{s}} \mathrm{dT} \\
& \dot{\mathrm{Q}}_{\mathrm{air}_{0}} \quad \mathrm{~W}_{\text {air }} 3_{\mathrm{T}_{\mathrm{ref}}}^{\mathrm{T}_{\mathrm{ar} 0}} \overline{\mathrm{C}} \mathrm{p}_{\text {air }} \mathrm{dT} \\
& \dot{\mathrm{Q}}_{\mathrm{H}_{2} \mathrm{O}_{0}} \quad\left[\mathrm{w}_{\text {air }} \quad \mathrm{D}_{\mathrm{H}_{2} \mathrm{O}_{\text {air }}}\right]_{\mathrm{T}_{\text {ref }}}^{\mathrm{T}_{\text {air }}} \mathrm{Cp}_{\mathrm{H}_{2} \mathrm{O}}[\mathrm{T}[\mathrm{dT} \mathrm{dT} \\
& \left.\mathrm{a}\left[\mathrm{w}_{\mathrm{s}} \quad \mathrm{D}_{\mathrm{H}_{2} \mathrm{O}_{\mathrm{s}}}\right]\right]_{\mathrm{T}_{\mathrm{ref}}}^{\mathrm{T}_{\mathrm{s} 0}} \mathrm{Cp}_{\mathrm{H}_{2} \mathrm{O}}[\mathrm{T}[\mathrm{dT} \\
& \dot{\mathrm{Q}}_{\text {gas }} \quad \mathrm{w}_{\text {gas }} 3_{\mathrm{T}_{\text {ref }}}^{\mathrm{T}} \overline{\mathrm{C}} \mathrm{p}_{\text {gas }} \mathrm{dT} \\
& \dot{\mathrm{Q}}_{\mathrm{cz}} \quad \mathrm{w}_{\mathrm{cz}} \underset{\mathrm{T}_{\mathrm{rcf}}}{3_{\mathrm{T}}^{\mathrm{T}}} \overline{\mathrm{C}} \mathrm{p}_{\mathrm{cz}} \mathrm{dT} \\
& \dot{\mathrm{Q}}_{\mathrm{rv}} \frac{\mathrm{D}_{\mathrm{CH}_{4}} \mathrm{~W}_{\mathrm{s}}}{\mathrm{M}_{\mathrm{CH}_{4}}} \mathrm{H}_{\mathrm{r}_{8}} \square \frac{\mathrm{D}_{\text {oth }} \mathrm{W}_{\mathrm{s}}}{\mathrm{M}_{\text {oth }}} \overline{\mathrm{H}}_{\mathrm{r}_{\text {oth }}} \\
& \dot{\mathrm{Q}}_{\mathrm{ACC}}\left\lceil\mathrm{w}_{\mathrm{s}} \overline{\mathrm{C}} \mathrm{p}_{\mathrm{s}} \square \mathrm{w}_{\mathrm{gas}} \overline{\mathrm{C}} \mathrm{p}_{\mathrm{gas}} \llbracket \frac{\mathrm{dT}}{\mathrm{dt}}\right.
\end{aligned}
$$

For many combustion processes, radiation is the dominant energy transport mechanism to surrounding surfaces, particularly when entrained particles are present. In a typical coal-fired furnace environment, radiation includes contributions from both particles and gases (Eaton et al., 1999). The heat exchange zone was modeled in the work of Ferreira et al. (2004). The interactions between the reaction chamber and heat exchange models occur via the heat flow rate to the waterwall, $\dot{Q}_{w}$ in Eq. (16), and the reaction system conditions (gas temperature and composition). In this case, the heat exchange model receives the information about the reaction system conditions and supplies the reaction chamber model with the heat flow rate to the waterwall, see Fig. 1.

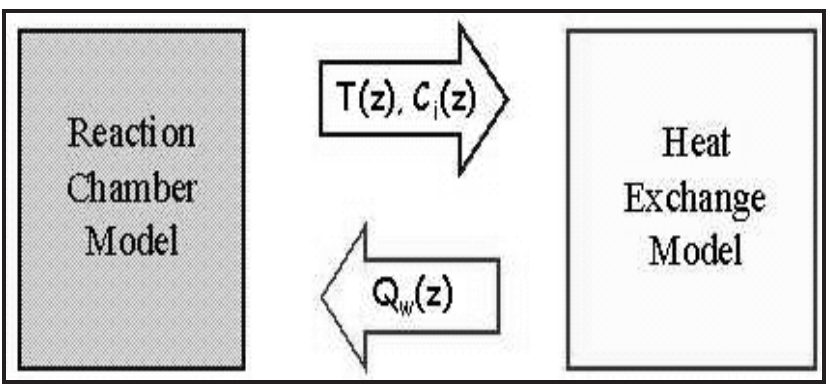

Figure 1. Interaction between the reaction chamber and heat exchange model.

\section{SIMULATION RESULTS}

The developed reaction chamber model was implemented in gPROMS (general Process Modeling System) simulator with proven capabilities for the simulation, optimization and parameter estimation of highly complex process. For simulations of the reaction chamber, the standard mathematical solver of this software, based on multiple step size integration method was employed (PSE, 2000).

The combustion gas composition is routinely measured with the purpose of controlling the combustion efficiency. In this way, there are carbon dioxide $\left(\mathrm{CO}_{2}\right)$ and oxygen $\left(\mathrm{O}_{2}\right)$ concentration measures in the combustion gas flowing out the boiler. The model was adjusted based on the measured data and using the maximum likelihood approach for parameter estimation, implemented in gPROMS, considering independent experimental deviation with normal distribution (PSE, 2000).

Table 4 shows the measured and model predicted percent concentrations of $\mathrm{O}_{2}$ and $\mathrm{CO}_{2}$ for the given operating conditions (coal and air flow rates). As a result of the estimation process, the air flow rate in the reaction chamber was increased $9.6 \%$, representing the expected amount of unmeasured air inflow rate. According to the results, it may be said that the model is able to predict the percent outlet concentrations of $\mathrm{O}_{2}$ and $\mathrm{CO}_{2}$ with acceptable accuracy and deviations of about $10 \%$.

The carbon dioxide formation essentially depends on the coal amount present in the input stream. The measured deviation of this stream, as well as the deviation of the measured inlet air flow rate, are the main reasons for the observed variance in the predict amount of $\mathrm{CO}_{2}$ formed during coal combustion, showed in Tab. 4.

The model analysis was carried out varying the input ratio of air and coal in the boiler. In order 
to verify if one reaction zone only is enough to predict the reaction chamber operation, with acceptable accuracy to become part of the Power Plant simulator, a steady-state energy production of $100 \mathrm{MW}$ was considered, modeled in two different ways. The first model uses one reaction zone (only one CSTR reactor), and the second model uses three reaction zones (three CSTR reactors in series).

The coal used in Power Plant is classified as sub-bituminous coal, which has a high weight percent of ash (about 54\% dry). Table 5 presents the coal analysis data for a representative coal sample. Several analyses showed that the variation in coal characteristics could be disregarded.

The results obtained from both models in a steady-state operation and the Power Plant measured data are presented in Tab. 6. This table shows similar results between the predictions of percent concentrations of $\mathrm{O}_{2}$ and $\mathrm{CO}_{2}$ in the outlet combustion gas composition.

Table 6 shows that the one-zone model predicts an average temperature of $1019 \mathrm{~K}$ along the total chamber volume (which is about $30 \mathrm{~m}$ high), and this value is higher than the three-zone model value predicted to the 3 rd zone.

Figure 2 compares the one-zone and threezone predictions for the gas temperature when the air/coal ratio fed into the boiler is varying. It can be observed that for an air/coal ratio up to 7.5 , the one-zone model underestimate the heat exchange in the steam superheating section due its lower outlet gas temperature. This figure also indicates that the temperature reaches a high value when the air/coal ratio is equal to the stoichiometric value.

Table 4. Measured and model predicted percent concentrations of $\mathrm{O}_{2}$ and $\mathrm{CO}_{2}$.

\begin{tabular}{|c|c|c|c|c|c|c|c|}
\hline $\begin{array}{c}\text { Coal } \\
\left(\mathrm{kg} \mathrm{s}^{-1}\right)\end{array}$ & $\begin{array}{c}\text { Air } \\
\left(\mathrm{m}^{3} \mathrm{~s}^{-1}\right)\end{array}$ & $\begin{array}{c}\% \mathrm{O}_{2} \\
\text { predicted }\end{array}$ & $\begin{array}{c}\% \mathrm{O}_{2} \\
\text { measured }\end{array}$ & $\begin{array}{c}\text { Deviation } \\
(\%)\end{array}$ & $\begin{array}{c}\% \mathrm{CO}_{2} \\
\text { predicted }\end{array}$ & $\begin{array}{c}\% \mathrm{CO}_{2} \\
\text { measured }\end{array}$ & $\begin{array}{c}\text { Deviation } \\
(\%)\end{array}$ \\
\hline 23.66 & 245.47 & 8.14 & 7.80 & -4.36 & 10.47 & 11.00 & 4.86 \\
26.99 & 260.15 & 6.95 & 7.00 & 0.67 & 11.47 & 12.00 & 4.42 \\
27.30 & 266.84 & 7.07 & 7.00 & -1.01 & 11.37 & 10.00 & -13.37 \\
27.60 & 265.99 & 7.74 & 7.00 & -10.50 & 10.81 & 12.20 & 11.40 \\
30.33 & 310.90 & 7.74 & 8.00 & 3.28 & 10.81 & 11.00 & 1.72 \\
30.64 & 299.45 & 6.49 & 7.00 & 7.23 & 11.85 & 11.40 & -3.95 \\
35.49 & 341.92 & 6.90 & 7.00 & 1.43 & 11.51 & 12.00 & 4.09 \\
36.10 & 357.82 & 7.49 & 7.00 & -6.95 & 11.02 & 12.40 & 11.10 \\
\hline
\end{tabular}

Table 5. Coal proximate and ultimate analysis (\% weight, dry) for the Power Plant simulation.

\begin{tabular}{|l|c|}
\hline Moisture & 3.6 \\
Volatile & 19.8 \\
Fixed carbon & 25.7 \\
Ash & 54.6 \\
Sulfur & 2.0 \\
Carbon & 32.3 \\
Hydrogen & 2.1 \\
Nitrogen & 0.7 \\
Oxygen + halogens & 8.3 \\
\hline Coal high heating value $\left(\mathrm{kJ} \mathrm{kg}^{-1}\right)$ & 13,000 \\
\hline
\end{tabular}

Table 6. Steady-state results for a $100 \mathrm{MW}$ energy production.

\begin{tabular}{|c|c|c|c|}
\hline & $\begin{array}{c}\text { One-zone } \\
\text { prediction }\end{array}$ & $\begin{array}{c}3^{\text {rd }} \text { zone } \\
\text { prediction }\end{array}$ & Measured \\
\hline$\% \mathrm{CO}_{2}$ & 10.40 & 11.00 & 11.00 \\
\hline$\% \mathrm{O}_{2}$ & 7.90 & 7.50 & 8.00 \\
\hline $\mathrm{T}$ out $(\mathrm{K})$ & 1018.82 & 959.10 & not available \\
\hline
\end{tabular}

All pulverized coal and air enter at the bottom of the chamber, producing a 'fire-ball'. In this zone, the wall temperature has the lowest value, and there is a lower temperature region next to the wall and a higher temperature region next to the flame (higher than $1400 \mathrm{~K}$ ). Near the top of the chamber, the gas reactions almost take place completely, existing a stream of hot gases that exchange heat with the waterwall. A common temperature profile inside the pulverized coal utility was shown by Eaton et al. (1999), based on 
experimental data, and it agrees with the comments above mentioned. Therefore, calculating only an average temperature is not enough, and the reaction chamber division in different zones provides a temperature profile that better represents the reaction chamber.

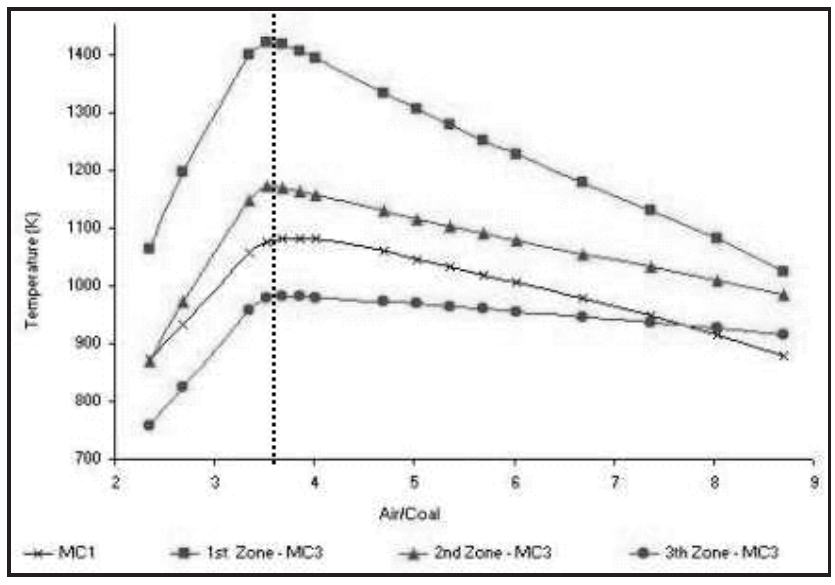

Figure 2. Steady-state temperature as a function of weight air/coal ratio.

Figure 3 shows the heat generation rate by the chemical reactions calculated by one-zone model. This figure confirms the necessity of an excess of air flow rate in relation to the stoichiometric quantity to take advantage of the heat generation rate by the chemical reactions.

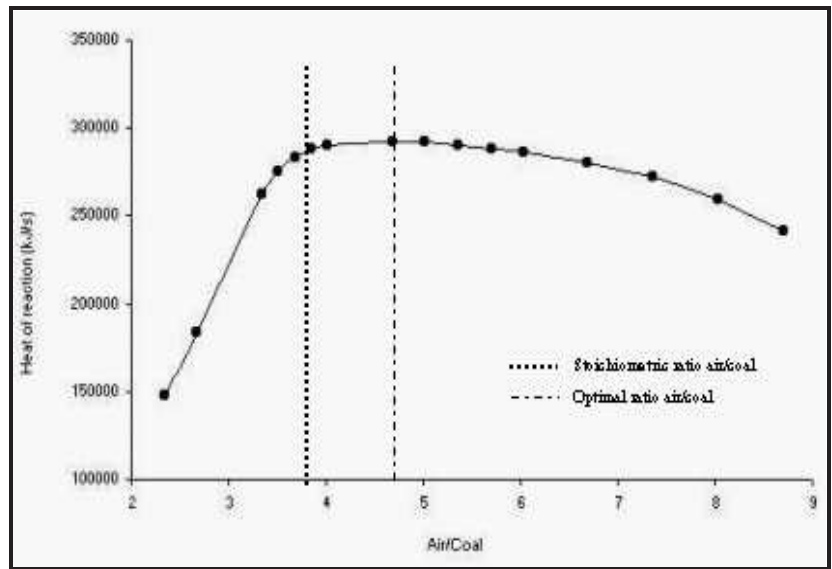

Figure 3. Heat generation rate at steady-state operations.

Furthermore, feeding the boiler with an excess air flow rate provides a low percent concentration of $\mathrm{CO}$ in the outlet combustion gas, as shown in Fig. 4. The optimal quantity of $\mathrm{O}_{2}$ corresponds to about $30 \%$ of excess air flow rate in the conditions simulated.

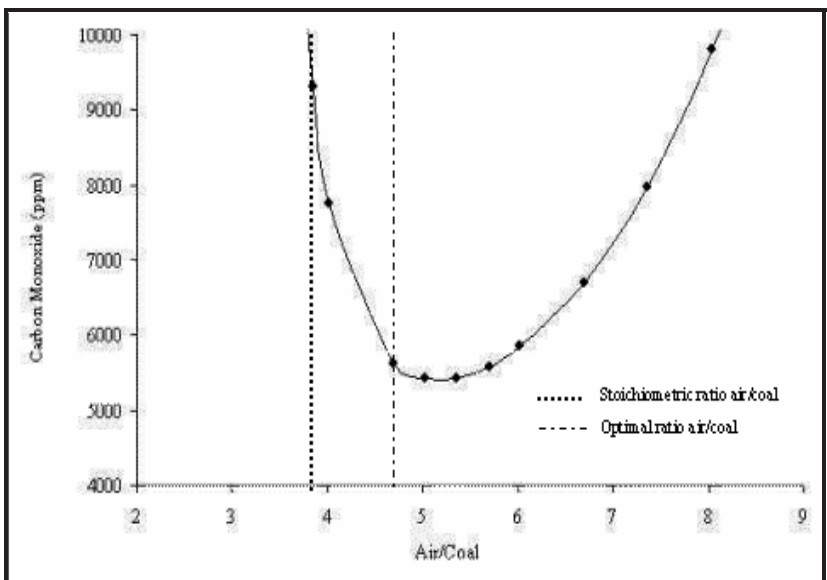

Figure 4. Steady-state CO concentration in the outlet combustion gas.

The decrease of the heat generation rate by the chemical reactions, after the optimal point, is due to a reduction in the carbon residence time in the reaction chamber by an increase of air flow rate. This fact is shown in Fig. 5, where it can be observed an increase of unreacted carbon present in the combustion chamber.

Figure 6 shows the outlet combustion gas composition. This figure shows an agreement between the one-zone and the three-zone model predictions. The percent concentration of $\mathrm{CO}_{2}$ is due to the amount of carbon present in the chamber and its value is the highest when the air flow is the stoichiometric value. As the inlet amount of air increases, the percent concentration of $\mathrm{CO}_{2}$ decreases. This variation in $\mathrm{CO}_{2}$ concentration is due to the increase of unreacted $\mathrm{O}_{2}$ and $\mathrm{N}_{2}$ concentrations, diluting the $\mathrm{CO}_{2}$ percent concentration in the combustion gas.

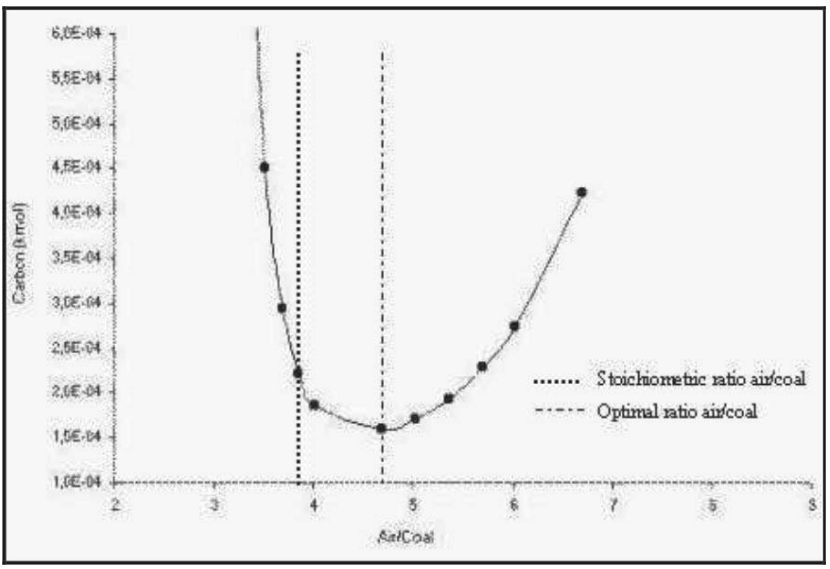

Figure 5. Carbon into the reaction chamber at steady-state operations. 


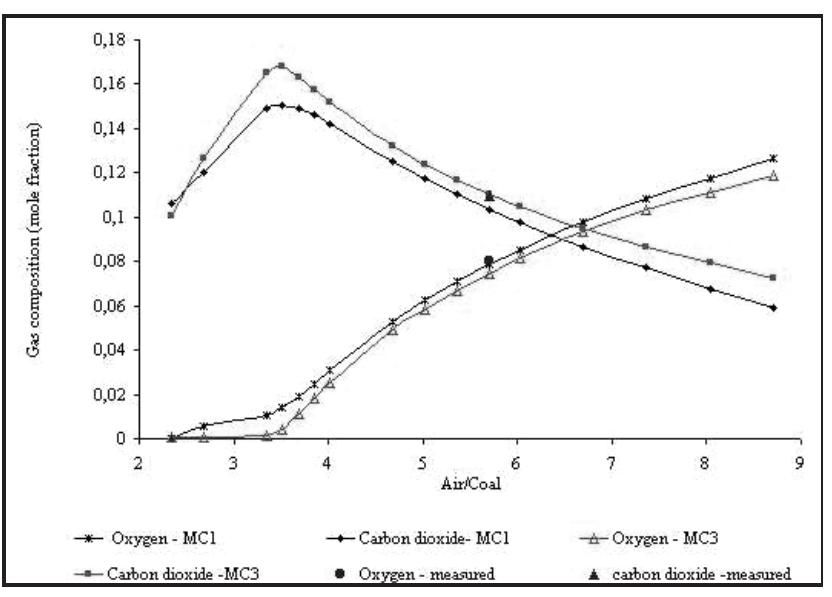

Figure 6. Steady-state $\mathrm{CO}_{2}$ and $\mathrm{O}_{2}$ percent concentration in the outlet combustion gas.

\section{CONCLUSIONS}

Regarding the developed model for the reaction chamber of a coal-fire boiler, the threezone model provides better results for the outlet combustion gas composition. But the predictions of both models (one-zone and three-zone) are suitable to set up the gas outlet composition of the reaction chamber.

About the predicted temperature profile for a steady-state of $100 \mathrm{MW}$ energy production, the one-zone model predicts a uniform temperature value higher than the temperature of the 3rd zone predicted by the three-zone model, underestimating the heat exchange in the steam superheating section. Consequently, the reaction chamber division in different zones is more suitable to account for the energetic boiler efficiency.

The computer simulation of the reaction chamber can give insights to reduce energy cost by improving combustion efficiency, and to yield a clean burning reducing pollutant emission. Also, the usage a power plant simulator can give insights to operator training.

\section{ACKNOWLEDGEMENTS}

The authors acknowledge with gratitude the technical support of CIENTEC-RS and the plant data supplied by CGTEE.

\section{REFERENCES}

ARTHUR, J. R., 1951, Reactions between Carbon and Oxygen. Transactions of the Faraday Society, Vol. 47, pp. 164-178.
BREWSTER, B. S., Hill, S. C., RADULOVIC, P. T., SMOOT, L. D., 1993, Fundamentals of coal combustion for clean and efficient use. Elsevier, Amsterdam.

DUTTA, S., WEN, C. Y., BELT, R. J., 1977, Reactivity of Coal and Char. 1. In Carbon Dioxide Atmosphere. Industrial Engineering Chemical Process Design Development, Vol. 16, No. 1, pp. 20-30.

EATON, A. M, SMOOT, L. D., Hill, S. C., EATOUGH, C. N., 1999, Components, Formulations, Solutions, Evaluation, and Application of Comprehensive Combustion Models. Progress in Energy and Combustion Science, Vol. 25, pp. 387-436.

FERREIRA, L. S., TRIERWEILER, J. O., MARCZAK, L. F., 2004, Simulação de uma Caldeira a Carvão Pulverizado: Troca Térmica, ENCIT. (in Portuguese)

HOWARD, H. C., - in LOWRY, H. H., 1963, Chemistry of Coal Utilization. John Wiley \& Sons, EUA, Suplementary Vol.

KANURY, A. M., 1975, Introduction to Combustion Phenomena. Gordon and Beach Science Publishers.

MITCHELL, R. E., 1988, Twenty-Second Symposium (International) on Combustion. The Combustion Institute, pp. 69.

NIKSA, S., 1996, IEA PER/31 Report, IEA Coal Research. London.

PERRY, R. H., GREEN D. W., 1999, Chemical Engineer's Handbook. McGraw Hill Handbooks.

PSE, 2000, gPROMS: Introductory User Guide. Process System Enterprise.

ROBERTS, D. G., HARRIS, D. J., 2000, Char gasification with $\mathrm{O} 2, \mathrm{CO} 2$, and $\mathrm{H} 2 \mathrm{O}$ : Effects of pressure on intrinsic reaction kinetics. Energy and Fuels, Vol. 14, pp. 483-489.

SMOOT, L. D., SMITH, P. J., 1985, Coal Combustion and Gasification. Plenum Press, New York.

THURGOOD, J. R., SMOOT, L. D., - in: SMOOT, L. D.; PRATT, D. T., 1979, Pulverizedcoal Combustion and Gasification. New York: Plenum Press, pp. 169.

WEIMER, A. W., CLOUGH, D. E., 1981, Modeling a Low Pressure Steam-Oxygen Fluidized Bed Coal Gasifying Reactor. Chemical Engineering Science, Vol. 36, pp. 549-567. 